\title{
Clonidine for neonatal abstinence syndrome: a single neonatology department's experience
}

\author{
PETJA FISTER ${ }^{1}$, MOJCA KRZAN², DARJA PARO-PANJAN \\ Corresponding author: \\ Darja Paro-Panjan \\ Department of Neonatology, Division of Paediatrics \\ University Medical Centre of Ljubljana \\ Bohoriceva 20, 1000 Ljubljana, Slovenia \\ Phone: + 38615228651 \\ Fax: + 38615224035 \\ E-mail: darja.paro@gmail.com
}

${ }^{1}$ Division of Paediatrics, Department of Neonatology, University Medical Centre of Ljubljana, Ljubljana, Slovenia

${ }^{2}$ Institute of Pharmacology and Experimental Toxicology, Faculty of Medicine, University of Ljubljana, Ljubljana, Slovenia

\begin{abstract}
Clonidine has been shown effective in reducing sympathetic hyperactivity in neonatal abstinence syndrome (NAS). The aim of this study was to analyze clinical and laboratory characteristics of a group of newborns treated with clonidine for NAS due to maternal drug addiction and due to withdrawal from opioid analgesic therapy. Only one full-term newborn presented with metabolic acidosis and hyperkalemia; in others no clinical or laboratory adverse effects were detected. This report emphasizes the importance of alertness to potential adverse effects of clonidine therapy, and discusses possible pathophysiological aspects of hyperkalemia and metabolic acidosis during treatment for NAS.
\end{abstract}

Key words: newborn, sympathetic hyperactivity, metabolic acidosis, hyperkalemia

\section{INTRODUCTION}

Although clonidine is generally approved only as an adjunctive treatment for opioid withdrawal, it has been shown as an effective medicine in reducing sympathetic hyperactivity in neonatal abstinence syndrome (NAS). (1) Many autonomic symptoms of opioid withdrawal like nausea, vomiting, cramps, sweating, tachycardia and hypertension, result from the loss of opioid suppression of locus coeruleus during NAS. By activating presynaptic alpha2-receptors, clonidine reduces increased sympathetic tone via a negative feedback mechanism. The opioid NAS pa- tients treated with clonidine in addition to reduced withdrawal symptoms benefit also from shorter duration of treatment and hospitalisation and are free of cardiovascular or sedation adverse effects. (2)

\section{CASE SERIES}

We analyzed clinical and laboratory findings of seven patients who were treated with clonidine because of NAS at the Department of Neonatology, Division of Pediatrics, University Medical Centre Ljubljana, Slovenia, from April 2013 to March 2014. Two patients were treated for NAS because of maternal drug addiction and five because of withdrawal from opioid analgesic therapy during intensive care (table 1). Routine daily controls of blood gases and ionogram revealed no abnormalities in six children, while in one- treated with clonidine for NAS due to maternal substitution therapy with methadone- hyperkalemia and metabolic acidosis was noticed. He was a full-term infant who developed NAS 48 hours after birth. The Finnegan score was 15 in three consecutive assessments and therapy with clonidine 1.1 $\mu \mathrm{g} / \mathrm{kg} / 6 \mathrm{~h}$ was started orally on the third day of life (PD3). (3) Before treatment with clonidine urine output was 3-4 mL/ $\mathrm{kg} / \mathrm{h}$; blood pressure and laboratory values were within normal limits. On the third day after introduction of clonidine (PD6), diuresis rose to $8 \mathrm{~mL} / \mathrm{kg} / \mathrm{h}$; blood urea and sodium concentrations were found to be in the high normal values, but creatinine, potassium and blood gas analysis were still normal. The boy was fed with formula milk, received additional hydration but no potassium supplementation. Blood urea and sodium concentrations normalized but after nine days of clonidine therapy (PD12) metabolic acidosis with hyperkalemia (pH 7.35, pCO2 $4.04 \mathrm{kPa}, \mathrm{HCO} 3$ $16.7 \mathrm{mmol} / \mathrm{L}, \mathrm{BE}-9 \mathrm{mEq} / \mathrm{L}$, anion gap $14.5 \mathrm{mEq} / \mathrm{L}, \mathrm{K} 6.6 \mathrm{mmol} / \mathrm{L}$, venous blood) was found; ECG showed peaked T waves. Glucose by intravenous infusion was introduced but as the potassium level reached $7.2 \mathrm{mmol} / \mathrm{L}$ the fast acting insulin was started and clonidine stopped (PD12). Potassium levels normalized three days after abrupt clonidine withdrawal (PD15). The Finnegan score after clonidine withdrawal was under 8 so additional therapies were not introduced. The boy was discharged home at the age of 18 days in a stable condition.

\section{DISCUSSION}

Hyperkalemia with metabolic acidosis, which we observed in one of our patients treated with clonidine, is a potentially lethal condition since it can provoke lifethreatening arrhythmias. In the broad differential diagnosis of acid-base and electrolyte imbalance, the plausible etiology could be probable or possible adverse reaction to clonidine, according to Naranjo's algorithm. (4) In a larger cohort, in a randomized, double-blind, controlled trial, where clonidine was added to opioid replacement therapy for opioid NAS, no hypertension, hypotension, bradycardia, or haemoglobin desaturation were observed; one infant developed supraven- 
tricular tachycardia and three children died in the first two months of life. The reported causes of death were myocarditis, sudden infant death syndrome, and homicide and it is not known whether clonidine contributed to the deaths. (5) Contrary to our study, the authors did not report any laboratory findings in the patient group studied.

Clonidine acts as an 2-adrenoceptor agonist at central and peripheral 2-adrenoceptors. In addition to its central effect, it also acts via postsynaptic alpha2A-Cadrenoreceptor subtypes located in the distal tubules of the human kidney. Therefore, the kidney is subjected to a decreased sympathetic tone that causes an increase in renal blood flow, which possibly presented with polyuria in our patient. Clonidinemediated diminished sympathetic tone also causes decreased plasma renin activity and consequently reduces aldosterone secretion, which prevents the excretion of $\mathrm{K}+$. This effect could be potentiated by aldosterone-resistance, which often occurs in newborns. (6) In addition, the lack of sympathetic tone also decreases extrarenal disposal of potassium, which additionally could lead to hyperkalemia. In our patient, hyperkalemia did not reappear after discontinuation of clonidine, so we suppose that laboratory findings after 9 days of therapy with clonidine indicated the pres- ence of type 4 renal tubular acidosis where hyperkalemia is the cardinal feature, and acidosis is mild when present. (7) Metabolic acidosis, which has been previously described as an adverse effect of clonidine, resolved spontaneously in all cases. (8)

In conclusion, we assume that metabolic acidosis type 4 with hyperkalemia in one of our patients was due to 1) decreased aldosterone secretion induced by clonidine, and 2) physiological resistance to aldosterone in human newborns, so we recommend regular controls of potassium blood levels after introducing clonidine for NAS.

Table 1. A case series of newborns treated with clonidine for neonatal abstinence syndrome.

\begin{tabular}{|c|c|c|c|c|c|c|c|c|c|c|c|}
\hline $\begin{array}{l}\text { Gender, } \\
\text { Gestationa } \\
\text { l age } \\
\text { (weeks), } \\
\text { Birth } \\
\text { measures }\end{array}$ & $\begin{array}{l}\text { Apgar } \\
\text { a score } \\
1 / 5 / 10 \mathrm{~min} \\
\text { after birth }\end{array}$ & $\begin{array}{l}\text { Additional } \\
\text { diagnosis }\end{array}$ & $\begin{array}{l}\text { Therapy } \\
\text { of the } \\
\text { mother/ } \\
\text { newborn }\end{array}$ & $\begin{array}{l}\text { Finnegan } \\
\text { score } \\
\text { before } \\
\text { clonidine } \\
\text { introduc- } \\
\text { tion }\end{array}$ & $\begin{array}{l}\text { Time } \\
\text { between } \\
\text { drug with- } \\
\text { drawal and } \\
\text { clonidine } \\
\text { introduc- } \\
\text { tion (days) }\end{array}$ & $\begin{array}{l}\text { Duration } \\
\text { of therapy } \\
\text { with cloni- } \\
\text { d dine (days) }\end{array}$ & $\begin{array}{l}\text { Maximal } \\
\text { dose of } \\
\text { clonidine } \\
(\mu \mathrm{g} / \mathrm{kg})\end{array}$ & $\begin{array}{l}\text { Blood gas } \\
\text { analysis }\end{array}$ & Ionogram & $\begin{array}{l}\text { Blood } \\
\text { pressure }\end{array}$ & $\begin{array}{l}\text { Neurologi- } \\
\text { cal assess- } \\
\text { ment at } \\
\text { discharge, } \\
\text { postnatal } \\
\text { age at } \\
\text { discharge } \\
\text { (days) }\end{array}$ \\
\hline $\begin{array}{l}\text { Female, } 40 \\
\text { LGA }\end{array}$ & 9/9/9 & $\begin{array}{l}\text { early onset } \\
\text { sepsis with } \\
\text { pneumonia } \\
\text { (S. pneu- } \\
\text { monia) }\end{array}$ & $\begin{array}{l}\text { midazolam } \\
\text { fentanyl }\end{array}$ & & 2 & 3 & $2 \mu \mathrm{g} / 12 \mathrm{~h}$ & normal & normal & normal & $\begin{array}{l}\text { axial hypo- } \\
\text { tonia, } \\
27\end{array}$ \\
\hline $\begin{array}{l}\text { Female, } 41 \\
\text { SGA }\end{array}$ & 9/9/10 & / & $\begin{array}{l}\text { buprenor- } \\
\text { phine }\end{array}$ & 16 & 3 & 7 & $3 \mu \mathrm{g} / 8 \mathrm{~h}$ & normal & normal & normal & $\begin{array}{l}\text { irritable, } \\
11\end{array}$ \\
\hline $\begin{array}{l}\text { Male, } 38 \\
\text { AGA }\end{array}$ & $7 / 7 / 9$ & / & methadone & 15 & 3 & 11 & $1,1 \mu \mathrm{g} / 6 \mathrm{~h}$ & $\begin{array}{l}\text { metabolic } \\
\text { acidosis }\end{array}$ & hyperK & normal & $\begin{array}{l}\text { hypertonia, } \\
16\end{array}$ \\
\hline $\begin{array}{l}\text { Male, } 39 \\
\text { LGA }\end{array}$ & $4 / 7 / 8$ & $\begin{array}{l}\text { meconium } \\
\text { aspiration } \\
\text { syndrome }\end{array}$ & $\begin{array}{l}\text { midazolam } \\
\text { fentanyl }\end{array}$ & & 2 & 5 & $2 \mu \mathrm{g} / 6 \mathrm{~h}$ & normal & normal & normal & $\begin{array}{l}\text { axial } \\
\text { hypotonia, } \\
\text { irritable, } \\
20\end{array}$ \\
\hline $\begin{array}{l}\text { Female, } 37 \\
\text { SGA }\end{array}$ & $3 / 7 / 7$ & $\begin{array}{l}\text { perinatal } \\
\text { asphyxia }\end{array}$ & $\begin{array}{l}\text { midazolam } \\
\text { morphine }\end{array}$ & & 2 & 7 & $2,7 \mu \mathrm{g} / 8 \mathrm{~h}$ & normal & normal & normal & $\begin{array}{l}\text { axial hypo- } \\
\text { tonia, } \\
21\end{array}$ \\
\hline $\begin{array}{l}\text { Male, } 35 \\
\text { AGA }\end{array}$ & $8 / 9 / 9$ & $\begin{array}{l}\text { apneic at- } \\
\text { tacks (RSV } \\
\text { bronchioli- } \\
\text { tis) }\end{array}$ & $\begin{array}{l}\text { midazolam } \\
\text { fentanyl }\end{array}$ & & 1 & 7 & $5,5 \mu \mathrm{g} / 12 \mathrm{~h}$ & normal & normal & normal & $\begin{array}{l}\text { axial hypo- } \\
\text { tonia, } \\
38\end{array}$ \\
\hline $\begin{array}{l}\text { Male, } 39 \\
\text { AGA }\end{array}$ & $9 / 10 / 10$ & $\begin{array}{l}\text { arte- } \\
\text { riovenous } \\
\text { malforma- } \\
\text { tion of cer- } \\
\text { ebral vein, } \\
\text { pulmonary } \\
\text { hyperten- } \\
\text { sion }\end{array}$ & $\begin{array}{l}\text { midazolam } \\
\text { fentanyl }\end{array}$ & & 1 & 7 & $2,2 \mu \mathrm{g} / 6 \mathrm{~h}$ & normal & normal & normal & optimal, 44 \\
\hline
\end{tabular}

AGA, appropriate for gestational age; hyperK, hyperkalemia; LGA, large for gestational age; SGA, small for gestational age. 


\section{REFERENCES}

1. Bada HS, Sithisarn T, Gibson J, Garlitz K, Caldwell R, Capilouto G, et al. Morphine versus clonidine for neonatal abstinence syndrome. Pediatrics 2015;135:e383-91.

2. Bio LL, Siu A, Poon CY. Update on the pharmacologic management of neonatal abstinence syndrome. J Perinatol 2011;31:692-701.

3. Finnegan LP, Connaughton JFR, Kron RE, Emich JP. Neonatal abstinence syndrome: assessment and management. Addict Dis 1975;2:141-58.

4. Naranjo CA, Busto U, Sellers EM, Sandor P, Ruiz I, Roberts EA, et al. A method for estimating the probability of adverse drug reactions. Clin Pharmacol Ther 1981;30:239-45.

5. Agthe AG, Kim GR, Mathias KB, Hendrix CW, Chavez-Valdez R, et al. Clonidine as an adjunct therapy to opioids for neonatal abstinence syndrome: a randomized, controlled trial. Pediatrics 2009;123:e849-56.

6. Martinerie L, Pussard E, Foix-L'Helias L, Petit F, Cosson C, Boileau P, Lombes M. Physiological partial aldosterone resistance in human newborns. Pediatr Res 2009;66:323-8.

7. Karet FE. Mechanisms in hyperkalemic renal tubular acidosis. J Am Soc Nephrol 2009;20: 251-4.

8. Hoder EL, Leckman JF, Poulsen J, Caruso KA, Ehrenkranz RA, Kleber HD, Cohen DJ. Clonidine treatment of neonatal narcotic abstinence syndrome. Psychiatry Res 1984;13:243-51. 